\title{
A Seven - Year Review of Accidental Kerosene Poisoning in Children at Aminu Kano Teaching Hospital, Kano
}

\author{
Belonwu R O MBBS FWACP, Adeleke SI MBBS, FWACP \\ Department of Paediatrics, Bayero University, Kano
}

\begin{abstract}
Background: Accidental ingestion of kerosene is a potential source of morbidity and mortality in children. The objectives of the study are to determine to magnitude of the problem and proffer feasible solutions to reduce the frequency of occurrence.
\end{abstract}

Methodology: The medical records of all cases of kerosene poisoning admitted into Paediatric Medical Ward and Emergency Paediatric Unit were identified and relevant data extracted and analysed.

Results: Kerosene poisoning constituted 55 (1.2\%) of cases of all paediatric admissions within the period (Jan 1999 Dec 2005). The study showed that children 4months to 8years were affected with peak age of 18 months. Thirty-four (61.8\%) of the cases were aged below 2 years which conforms to findings in earlier studies in Nigeria. Main clinical feature was cough with difficulty in breathing in 52 (94.5\%) of cases. Others features noted were central nervous system involvement (14.5\%), vomiting (20\%), and fever $16(29.1 \%)$. There were 3 deaths giving the mortality of $5.5 \%$.

Conclusion: The study has revealed that kerosene poisoning is a significant cause of morbidity and mortality. Government policies that will enhance the standard of living of people and education of parents/care givers are the identified imperatives for reduction of the problem.

Keywords: Accidental, Kerosene, Poisoning, Review.

Date accepted for publication $12^{\text {th }}$ June 2008

Nig J Med 2008; 380 - 382

Copyright $@ 2008$ Nigerian Journal of Medicine

\section{Introduction}

Kerosene is a low viscosity aliphatic hydrocarbon which is poorly absorbed from the gastrointestinal tract'. However, the major hazard associated with kerosene ingestion is aspiration into the respiratory tract. Kerosene is directly irritant to the airways and produces bronchiolar edema and spasm. Kerosene tends to spread widely over the lining of small airways and alveoli and hence disrupts cell membrane integrity culminating in inflammatory response characterised by hyperaemia, vascular thrombosis, haemorrhage and edema. Additionally, the alveolar surfactant layer is dissolved with consequent alveolar collapse and atelectasis. The resultant hypoventillation with hypercabia produces a mixture of respiratory and mietabolic acidosis. Secondary bacterial infections may supervene. Ingestion of kerosene produces clinical manifestations varying from no apparent effect to death ${ }^{2}$. Kerosene ingestion has been established to be a significant cause of childhood morbidity and mortality ${ }^{3.8}$. Children who are in 1-3year age- group are mostly affected ${ }^{48}$. The common symptoms of kerosene poisoning are cough, dyspnea, fever, diarrhea, vomiting, central nervous system depression which can range from drowsiness to coma and may be associated with seizure disorder. In 1962, a subcommittee of the American Academy of paediatrics reported the annual incidence of kerosene ingestion in the United States as 28,000 cases with 83 deaths. ${ }^{9}$ Although there are no National figures for Nigeria, a few studies have been conducted in various parts of the country. ${ }^{5}$ There has been no detailed publication on kerosene poisoning among children in Kano. This retrospective review aims to document the pattern of kerosene poisoning in Kano, and to compare the result with findings else where.

\section{Materials and Methods}

The medical records of children admitted to the Emergency Paediatric Unit (EPU) and Paediatric Medical Ward of Aminu Kano Teaching Hospital, Kano with kerosene poisoning during a 7-year period (January 1999 December 2005) were reviewed. The data extracted from the records included the patient's age, sex, date of admission, clinical features, duration of stay in hospital and outcome. The extracted data were entered in designated forms, checked and corrected for errors; they were coded, entered into personal computer and analysed using SPSS statistical package. Percentages and ratios were used to determine relationships. 


\section{Results}

During the 7-year period under review there were 4490 paediatric admissions of which $55(1.2 \%)$ were cases of kerosene poisoning. The yearly admissions due to kerosene poisoning and percentage of total paediatric admissions are shown in Table I

\section{Age and Sex Distribution}

The children were aged 4 months to 8 years with a mean age of 26.6 months and a peak age of 18 months. Thirtyfour $(61.8 \%)$ of the 55 cases were below 2 years of age (Table II). There were 35 males and 20 females, a male to iemale ratio of 1.75:1. Only 5 children were above 5 years.

\section{Clinical Features}

The commonest presenting features were cough and difficulty in breathing occurring in $52(94.5 \%)$, followed by vomiting in $20(36.4 \%)$; fever in $16(29.1 \%)$, central nervous system depression in $8(14.5 \%)$ and diarrhea in 1 $(1.8 \%)$. CNS involvement was mostly manifested as coma, drowsiness and restlessness. Those who presented with respiratory difficulties had pneumonia which was confirmed radiologically.

\section{Morbidity and Mortality}

Eleven (20\%) of patients were discharged within $24 \mathrm{hrs}$ of admission while $6(10.9 \%)$ patients stayed beyond 4 days. The mean duration of hospitalization was 47.4 hours (range 2 hours 11days). There were 3 deaths, an overall mortality of $5.5 \%$.

Table I: Yearly admissions of 55 cases of kerosene poisoning

\begin{tabular}{cccc}
\hline Year & No. of cases & Total Paediatric Admissions & \% of Total \\
\hline 1999 & 4 & 377 & 1.06 \\
2000 & 1 & 520 & 0.19 \\
2001 & 17 & 615 & 2.76 \\
2002 & 1 & 557 & 0.18 \\
2003 & 10 & 769 & 1.30 \\
2004 & 11 & 795 & 1.38 \\
\hline 2005 & 11 & 857 & 1.28 \\
Total & 55 & 4490 & 1.22 \\
\hline
\end{tabular}

Table II: Age distribution in 55 cases of kerosene poisoning

\begin{tabular}{ccc}
\hline Age (Yrs) & No. of cases & \% Of Total \\
\hline < 1year & 5 & 9.09 \\
1 & 29 & 52.73 \\
2 & 11 & 20.00 \\
3 & 4 & 7.27 \\
4 & 1 & 1.82 \\
5 & 1 & 1.82 \\
$>5$ & 4 & 7.27 \\
Total & 55 & 100.00 \\
\hline
\end{tabular}

\section{Discussion}

The present retrospective study shows that accidental poisoning with kerosene is an important health problem constituting $1.2 \%$ of the total number of admissions to the paediatric wards over a 7 year period. This value is higher than those reported by Izuora and Adebowale in Saudi Arabia ${ }^{4}(1 \%)$, Fagbule and Ojuawo in $1 / 0 i^{8}$ $(0.05 \%)$ and Ganga et al in India ${ }^{10}(0.09 \%)$. The relative higher percentage in the current study may be explained by several reasons which may include increasing human populations, relative poverty warranting that households still use kerosene instead of gas for heating and lighting, increasing participation of mothers in paid jobs and trading and so poor supervision of young ones and social tensions leading to less care in handling potentially poisonous substances. The yearly variations in the occurrences of kerosene poisoning in the study reflected the trends in the society within these periods. The first four years reflected the relative plenty and scarcity alternately which concided with attempts by the government to liberalise the marketing of petroleum products. In consonance with the fluctuations, the availability of kerosene in the homes varied paripasu. In the last 3 years (2002 - 2005) availability of kerosene was fairly constant and that probably reflected in the similar yearly percentages in incidences of kerosene poisoning. The peak age incidence at 18 months is comparable to the findings at $\| \mathrm{lorin}^{5,8}$ and $\mathrm{lbadan}^{7}$. Children at this age are highly mobile, curious and would put to mouth any familiar containers and their contents. The male to female ratio of 1:75:1 is comparable to the findings of 1.7:1 at Ilorin by Fagbule and Joiner ${ }^{5}$.The preponderance of male to female patients is in line with most earlier studies in Nigeria ${ }^{5.8}$ and elsewhere ${ }^{4,10-12}$ This finding may be a reflection of the more adventurous nature of boys; a view shared by Onedeko at lbadan? The finding of only 5 cases of kerosene poisoning after 5 years is comparable to the llorin series ${ }^{5}$ where only 4 cases were found. Our study showed that a 4 month old child was involved. This was a case where the mother had stored kerosene in paracetamol syrup bottle but forgot that she had done so and gave it to the child when he developed fever.

Pulmonary complications in $94.5 \%$ is comparable to the $89.9 \%$ in llorin $^{5}$ but higher than the $73.6 \%$ reported in Zaria $^{6}$. The respiratory signs and symptoms most often result from the attempt by parents/caregivers to induce emesis which would lead to aspiration pneumonitis. Moreover, some people injudiciously administer milk 
and palm oil as antidotes to these children which increases the risk of pneumonitis as observed in earlier studies in Nigeria, ${ }^{5,6.8}$. In some of our patients, such practices were reported. Neurologic complications in $14.5 \%$ is lower than the $26.5 \%$ reported from $\|^{\prime}$ orin $^{5}$. However, in Zaria ${ }^{6}$ and in a series reported earlier in llorin by Fagbule and Ojuawo ${ }^{8}$, no case of central nervous system involvement was observed. More patients (20\%) were discharged within 24hours compared to the study in Ilorin ${ }^{5}$ where only $11.9 \%$ of the patients were discharged within the same time. Probably less severe respiratory symptoms and fewer patients in our series with neurologic involvement may explain the disparity. Long hospital stay in some of the patients implied economic losses on the part of the parents as well as disruptions in family dynamics. The mortality of $5.5 \%$ is comparable to that of $4.6 \%$ reported from India ${ }^{10}$ but much higher than the figures from Zaria $^{6}(1.6 \%)$, Ilorin ${ }^{5}(0.9 \%)$. The higher mortality documented may be explained by the severe respiratory symptoms and the marked neurologic involvement in the 3 cases that died. Probably absence of intensive care facilities which these cases required contributed to the higher mortality in our series.

\section{References}

1. KentRO, MichaelAM. Toxicology and Accidents. In Rudolph A M, Hoffman J I, Rudolph C D, eds. Rudolph's Paediatrics. Connecticut:Appleton and Lange, 1996:805-878.

2. Wolfe $B M$, Brodeur AE, Shielf J B. The role of gastrointestinal absorption of kerosene in producing pneumonitis in dogs. $\mathrm{J}$ Paediatr. 1980; 76: 96773.

3. Walton $W W$. An evaluation of poisoning prevention packing. ActaPaed 1982; 69: 36370.

4. Izuorah G I, Adebowale A. A seven year review of accidental poisoning in children at a military hospital in Hafral Batin, Saudi Arabia. Ann Saudi Med 2001; 21: 1316.

5. Fagbule D O, Joiner KT. Kerosene poisoning in childhood: a 6year prospective study at University of llorin Teaching Hospital. WAfr J Med 1992; 11: 116121.
The control and prevention of kerosene poisoning requires a comprehensive approach which should include health education, measures to make the home environment child friendly, enactment and enforcement of relevant regulations as well as provision of intensive care facilities in all secondary and tertiary health facilities. The public should be made aware of the dangers inherent in kerosene poisoning,. In particular, during the dry months, patients/caregivers should be made to give the children water at chosen intervals so that the toddlers don't seek for water in just any container within their reach thereby poisoning themselves unknowingly. Considering the harsh economic situation in Nigeria and the frequent scarcity of cooking gas in Nigeria, kerosene will continue to be used in the homes. It is the responsibility of the government to initiate plans on enhancing the living standards so that the need for kerosene in the homes will be reduced.

6. Ango S S, Yakubu A M. Accidental Childhood poisoning in Zaria. Nig JPaed. 1982; 9: 105109.

7. Onedeko M O. Domestic Accidents among Rural and Urban children. Nig JPaed. 1983; 10: 2327.

8. Fagbule D, Ojuawo A. Accidental Childhood poisoning in llorin. Nig JPaed. 1986; 13:21 25.

9. Subcommittee on Accidental poisoning: Cooperative kerosene poisoning study. Paediatr 1962; 29:648 658

10. Ganga N, Rajarajeswari G. Poisoning in children. Indian Pediatr. 2001; 38: 208.

11. Mahdi A H, Taha S A, Al-Rifai M R. Epidemiology of accidental home poisoning in Riyadh Saudi Arabia. J Epidemiol Community Health 1983; 37: 2915.

12. El Mouzan M I, Elageb A, Ali N K. Accidental poisoning of children in the Eastern Province. Saudi Med J 1986; 7: 231 6. 